\title{
Literary Aesthetics in the Narration of Dagara Folktales
}

\author{
Martin Kyiileyang \\ Department of English Education, University of Education, Winneba, Post Office Box 25. Winneba, Central Region, Ghana, West Africa \\ E-mail: mkyiileyang@gmail.com
}

Doi:10.7575/aiac.alls.v.7n.6p.221

Received: 02/10/2016

URL: http://dx.doi.org/10.7575/aiac.alls.v.7n.6p.221

Accepted: 17/11/2016

The research is financed by authorities of the University of Education, Winneba through my monthly salary and the Book and Research Allowances.

\begin{abstract}
Dagara folktales, like other African folktales, are embedded with various literary aesthetic features related to structure, language and performance. This paper examines major literary aesthetics found in Dagara folktales. The methodology used is based on the collection, analysis and interpretation of selected Dagara folktales gathered through fieldwork. The focus of the paper is on the structure and the language of Dagara folktales. The argument of this paper is grounded on the Structuralist Theory as seen in Gerard Genette's Narrative Discourse which offers the basic constituents and techniques of narrative. Genette proposes various categories of narrative which cover Time, Mood and Voice. Genette's narrative structure suggests that the various categories and subcategories emphasise that the narrative is a complex structure in which the narratee is largely present in the various strata of the structure. Genette is concerned with the macro-text of the recit, that is, the ordering of events in the narrative. The study revealed that there are similarities and differences in the structure and the language of Dagara folktales in relation to other African folktales.
\end{abstract}

Keywords: Dagara People, Folktale, Literary Aesthetics, Performance, Structuralist Theory

\section{Introduction}

This introduction serves as background knowledge on the aesthetics approach in literature and the narration of folktales. Folk Culture is the type of culture that deals with the customary beliefs, social forms and material constructions of specific folk groups. Therefore, folk culture encompasses closely associated elements such as speech patterns, social actions and activities, beliefs, behaviours, ideology and artifacts specific to the group. Folk culture was considered something which existed only within small, isolated, homogeneous groups whose members were generally illiterate and lived in some form of pre-urban society. Earlier studies conducted by scholars focused on groups considered as representatives of peasants or ethnic minorities. (Allison, 1997, pp. 316-317; Ed. Thomas A. Green). The culture of the Dagara of Nandom equally has customary beliefs and some of these can be identified in their folktales and other forms of oral literature.

The art of narrative is a highly aesthetic enterprise. There are certain basic aesthetic elements which interact in welldeveloped stories. Such elements include the narrative structure, with identifiable beginnings, middles and ends, or exposition-development-climax-denouement, with important inciting incidents, normally constructed into coherent plot lines. There is also a strong focus on temporality that includes retention of the past, attention to present action and future anticipation, a reasonable focus on characters and characterisation which is arguably the most important single component of the novel. The sound of the human voice, or many voices, speaking in a variety of accents, rhythms and registers are all significant to narrative performance.

Folktales are part and parcel of folk culture. In Fischer's (1963, p. 236) comprehensive article on the sociopsychological analysis of folktales, he posits that the term 'Folktale' is broadly used to describe and include any traditional, dramatic and oral narrative. This also includes myths which deal with the supernatural, moralistic tales and those meant mainly for entertainment. His views are corroborated by several other scholars some of whom include Thompson (1955, pp. 482-488). Folktales are classified according to their social function, content, structure and typical audience. He stresses that though classification of folktales sometimes creates uncertainty and ambiguity at a given time and place, it is nevertheless significant for this leads to a better understanding of the tales. For example, in one society a particular tale may be regarded as an important myth while in other societies it is narrated for mere entertainment. Surprisingly, this can occur in societies sharing variants of the same narrative. This creates different opinions about what is sacred and what is not as some myths contain comic interludes. It is also important to note that as a distinguished group of folklore, folktales may be regarded as a major division of expressive culture which also includes drama, ritual, music and plastic art and dance. This can be contrasted with practical culture including technology, economy, politics and social structure. Expressive culture is characterised by the expression and the manipulation of the emotions of the participants apart from the fact that these same participants can communicate objective information. 
Philosophical approaches to the subject of aesthetics are focused on the perception f beauty in the experience of art. These approaches define those formal features within folklore that constitute its artfulness in communal and personal terms. Folklorists speak of aesthetic issues in terms of style, artistry, and the relation of tradition and innovation. An aesthetic analysis may pertain to a single genre or to the folklore of an entire community. In either case, aesthetic standards may be examined from a contrastive perspective that is, in relation to some other genre or community or from an in-group perspective. Folkloristic research in aesthetics contributes to theoretical understandings of cultural relativism and the importance of communal tastes in the creation of art. The topic of aesthetics also holds importance for public sector researchers, as it raises issues related to the evaluation and presentation of folklore (DuBois, $1997, \mathrm{p}$. 13; Ed. Thomas A. Green).

The aesthetic experience is often a pleasurable and desirable one, an experience which gives meaning to life. The Dagara of northwestern Ghana are no exception to this experience. Their folktales are embedded with metaphorical, paradoxical and ironical expressions and images among other literary features. These render them beautiful not only in embellished language but also the structure. One way of incorporating pleasure into a theory of aesthetic experience might be to hold that a subject can rightly be said to have an aesthetic experience if her mental activity is united and made pleasurable by being tied to the qualities of the object of aesthetic attention (Beardsley 1969 cited in Boundas, 2007, p. 341).

Theories of aesthetic experience may be divided into two kinds according to the kind of feature appealed to in explanation of what makes experience aesthetic. Internalist theories appeal to features internal to experience, typically to phenomenological features, whereas externalist theories appeal to features external to the experience, typically to features of the object experienced. Beardsley's views on aesthetic experience make a strong claim on our attention, given that Beardsley might be said to have authored the culminating internalist theory as well as the founding externalist one.

Magoulick (2012) has strongly indicated the dynamics of folklore and ethnography since the 1960's which have shifted from mere collection and categorization of folklore to synthesis and understanding of their creations in their own terms. Since then, scholars such Hymes and Tedlock (1975) endeavoured to present texts that they developed among Native Americans. Nowadays, modern researchers on folklore now allow literature and narratives to speak for the people and their various cultural practices undertaken by scholars. With reference to folktales, Performance Theory is indispensable for modern scholars working on field-collected narratives. Performance Theory aims at rendering texts skillfully artful so that the aesthetic values can be delineated according to the comprehensive language, speech patterns and figures of sound inherent in the texts.Bauman (1983, p. 2) and Jahner's (1983, p. 16) endorsement of the context of performance of oral narratives makes sense in the study and analysis of folktales. This approach falls in line with Yankah's (1989) passionate call for the use of proverbs in the right context.

Kabaji (2012) examined the meaning and aesthetics of the Maragoli folktale in Kenya. The study covered a sample of eight Maragoli folktales selected on the basis of their popularity. These were carefully analysed in order to demonstrate certain features about the Maragoli folktales. The first point to note is the fact that the Maragoli folktale is properly structured and the structural patterns express meaning both at the surface level and the deeper level. The researcher argued that the Maragoli folktale manifests what the Maragoli consider good or bad, beautiful or ugly. Additionally, the tales express views about the world as seen by the Maragoli. The various modes through which the folktales appeal to the aesthetic sensibilities of the audience are examined. Some of these include the manipulation of the invariant structure, the integration of songs, voice modulation, body movement and gestures. Collectively, all these contribute to the aesthetic appeal of the audience at the time of performance. Kabaji (2012) used an interdisciplinary approach namely: structural, symbolic and socio-psychological approaches. The structural patterns of the eight tales were outlined and this uncovered the wider implications beyond the linear clarity. The dominant structural patterns are examined to reveal their surface and deeper meaning as well as their role in demonstrating the systematic way in which folktales are narrated in the context of performance.

Sekoni's analysis of Nigerian folktales (cited in Okpewho's, 1992, p. 140) reveals that there are several components of oral narrative performance. However, three of these are intertwined and as such inseparable. These are captivation of audience, participation and retention of audience and the skilful transfer of cognitive experience to the audience.

Every narrator must have a good and charming voice. Additionally, the narrator must be a good user of the language of narration and finally his ability to use his body effectively to enhance the performance. The opening formula of narrators is often linked with the narration of the tale. As part of the use of language, songs are used in the narrativeperformance. They are linked with the themes of the tales and there is a relationship that exists between them. Tonal expressions are also important in a folktale performance session. These constitute the narrator's ability to use his voice and body to convey the emotions of characters. Sekoni, (cited in Okpewho, 1992, p. 141) has the following to say:

after the narrator's beautiful voice, skilful use of language and effective manipulation of his body have attracted the attention of the audience to the narrative experience, the narrator still needs to retain or hold this attention till the end of the story.

Additionally, Sekoni's analysis shows that the narrator does not only captivate the physical attention of the audience but he also draws their emotive and cognitive attention. Cognitive satisfaction refers to the ability of the narrator/performer to relate the individual images to the theme. Diverse images in the story whether metaphorical, paradoxical, ironical or 
sarcastic must in their totality achieve some clarity of meaning. The ability of the narrator to manipulate the feelings of the audience during performance matters a lot .Magoulick (2012) corroborates this fact about performance.

It is important to consider the views of other scholars on the manifestation of images in the course of performances. A renowned authority in African Oral Literature delineates the importance of imagery in Oral Literature in the following words:

Images may be expressed directly or indirectly. A narrator or a singer may describe a scene or an event with little reference to anything else but with such a powerful choice of words that are deeply touched either with admiration or with shock". These images can be concrete, simple, complex or symbolic in nature depending on where they occur or how they are used in the story (Agyekum, 2007, pp. 52-54).

In a collection of West African tales (that is, Dagara folktales), various images are portrayed. The baobab tree whose fruits must be harvested for Orphan's mother-in-law (who has just delivered a baby) suggests a huge image of impossibility. Though the tree is very tall and gargantuan in nature, it is surmounted by Monkey:

... at nightfall Monkey climbed the baobab tree and harvested all the fruits". This feat enabled Orphan to pass the hard test set by the Chief. The image of poison is also clearly portrayed in cobra which bit and eventually killed the bull that Orphan was asked to slaughter all by himself. Everybody thought it was actually Orphan who killed the bull by his might ((Kyoore, 2009, pp. 4, 6).

Imagery is very much pronounced in "Moral Lessons a Man Gives to the Children". The names of the six sons are typical examples of particular pictures that the narrator tries to portray. "Zume-wa-kpe" (Intuition-just-entered or Premonition), "Nyubri-Bang-Sor" (Sniff-to-know-the Path/Way), "Kpe-nyu-kuoə" (Go inside-and-Drink-Water), "Urberdegr" (Scrub-and-Remove-the Dirt), "Dagol” (Cudgel), "Zusogkole" (Catch-in-mid-Air). All of them equally played significant roles in the intuition, recovery, search and final salvation of their father in this dilemma tale. The socalled Goat is named 'Tizayelle' (All-of-us-our-Problems) in Chapter Two and from the behaviour of this character, one knows that Rabbit, Hyena and the Dog are incompatible and can never co-habit. The message of incompatibility is strongly related in this story (Kyoore, 2009, pp. 8-10). These names are typical narrative complements to the underlining message of the whole story.

Closely related to imagery is comparison in Dagara folktales. The image can be a simile or a metaphor where indirect and direct references are made respectively. Most of these images can be found in Kyoore's (2009) collection. Paradox is another common feature in Dagara folktales. Additionally, the technique of allusion can also help people improve their language by borrowing from other images and ideas from imaginative literature such as folktales. Another device that also plays an important role in the narration of stories is symbolism. Symbols are commonly used in rituals and even divination matters with deep spiritual intensity. The story in Chapter Six of Kyoore'a collection is full of various images and symbols which reiterate certain ideas of the narrator. Some of these ideas include knowledge, wisdom and mystery as characters are destroyed magically and revived under mysterious circumstances (Kyoore, 2009, pp.18-28).

\section{Background of the Dagara of northwestern Ghana}

The Dagara are a group of people in the Upper West Region of Northern Ghana. The main area of settlement is Nandom and Burkina Faso. However, some of them are reported to have settled in present day Ivory Coast as well. In Ghana, the Dagara form the greater part of the population of Diocese of $\mathrm{Wa}$ and their relatives in the Diocese of Diebougou of Burkina Faso. (Bekye, 1991, pp. 93-94) The Dagara originated from the Mole-Dagbani peoples of the Lake Chad region. They are part of the Gur-speaking (Mabia) group of West Africa. They have always maintained and sustained their traditional, social, political and religious systems of organisation. Dagara traditions include farming, sacrifices offered to almighty God, marriage, dowry, initiation rites, inheritance, nomenclature, art and craft such as weaving, carving and pottery. All these originated from their ancestors. The Dagara have always settled in villages.

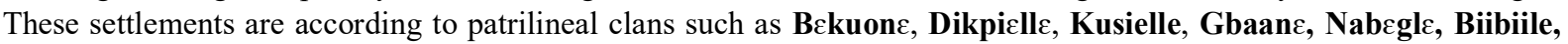
Berwuole, Metuoll $\varepsilon$ and Zage. Apart from these patrilineal clans, there are also matrilineal clans. Some of them include Somda, Kpoda, Meda, Som $\varepsilon$, Dabire, Kambire and Hicn.

\section{Dagara oral literature and their art of performance}

Dagara oral literature is wide in scope and much time must be spent on it by researchers and scholars on Dagara traditions and culture in general. The study of this oral literature can be viewed in several perspectives. In the first place, oral traditions in general, xylophone tunes, riddles, dirges, drum language and artworks are prominent in their oral literature. Additionally, folktales, myths, proverbs and music are also other significant aspects of Dagara oral literature. Generally, Dagara folklore is indispensable to the understanding of their literature. The Dagara as part of the Dagaaba in the Upper West Region are blessed with ingenuity in their interpretation of the cosmology. The physical and social environments as well as the world of their ancestors are believed to be closely related. Thus, man's life on earth is greatly controlled by all kinds of forces both physical and spiritual in nature.Dagara music shares certain common features with the music of other cultures such as the Sisaala, the Waala, the Dagomba, the Frafra, the Kusaasi and Mamprusi. The main musical instrument of the northwestern part of the country is the xylophone which is often supported by a drum or a drum ensemble. 
Various aspects of Dagara Oral Tradition include the singing of dirges, playing of the xylophone, playing dalari (small drums) and 'gangai' (big drums) on special occasions and during entertainment, playing wind instruments such as the

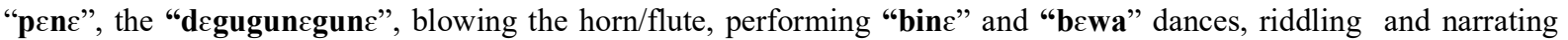
folktales. Women can also exclusively engage in "kaari" and "nuru loba" - types of entertainment based on clapping of hands and certain dances performed by only women. All these activities require some requisite skills and techniques. It is a well-known fact that anybody who wants to learn any of these aspects of Dagara oral arts must acquire a good amount of knowledge and skill and techniques before attempting to perform them in public. For example "bine"and "bewa" are vigorous dances which do not only require physical energy but also special dexterity and innovation in order to attract public attention. People can claim to know how to perform these dances but such dances involve good timing, collective response from other dance partners (if that is a group performance) and expert lead dancers who direct the kind of style or skill to use at a point in time.

Similarly, young men who want to learn how to sing dirges in public consciously observe, learn and practise on their own particularly when they are alone or engaged in activities such as weeding on the farm, harvesting crops or hunting alone or in a group. Though there are some dirge singers with inborn talents, the art of singing dirges is acquired by dint of hard work. It must be stressed that the art of performing dirges is a competitive one and this explains why performers on funeral occasions try to outdo one another unwittingly. It is a common practice that performers who cannot cope with the pitches raised through xylophone music, often drop out and keep silent when experts supersede them in the art of performance.

Apart from uttering words, there are several other interesting things connected with dirge performance. During performance most cantors cast insinuations at each other and aggressively abuse one another. Some even engage in vituperative diatribe. In most instances, such performers use verbal expressions to insult or chastise the deceased and/or his/her relatives as a form of humiliation or retaliation. A common idiomatic expression often used during dirge performances is "duori kulo nyaaru"; literally translated as (salt consciously put in specific quantities to attract buyers). This idiomatic expression is a bait laid by dirge singers with the intention of provoking other competitive performers to react automatically. Inexperienced performers are likely to react in anger but the experts know how to manoeuvre a reply to competitive rivals in the art. In most instances, rivals react but the maturity of the respondents will show in the kind of message that is given back to silence the baiter.

There are several reasons why the art of dirge performance has increased tremendously in Dagaaba society and even in the urban centres. The main reason for singing dirges is to console and condole with the bereaved family. The performer often tries to offer genuine sympathy to the bereaved family. In fact, the act of dirge performance among the Dagaaba is aimed at drawing the crowd of mourners and sympathisers to a collective, deep sense of sympathy towards the bereaved family. The evocation of this collective sympathy induces greater mourning. Additionally, the singing of dirges also arouses the emotions of the bereaved family as it calls for great intensification of mourning. A third reason why dirge performance has attracted a lot of practitioners is indirectly linked with production of xylophone music. Many xylophonists on whom the cantors rely also use the occasion to practise the art of playing the xylophone so as to keep the art and the practice alive. Some xylophonists are dirge singers at the same time so they know the kind of xylophone music to produce particularly during the funerals of elderly and important people in society to attract attention and commendation from the crowd of mourners. Aesthetically good musical texts attract competitive dirge performance and dancing on the death of elderly or significant people in society. Thus, the xylophonists also ply their trade to earn a few coins and public recognition for their dexterity.

Moreover, the art of performing dirges has attracted great economic value nowadays among the Dagaaba and the same for other related ethnic groups. In the olden days, cowries were used during funeral occasions when the deceased was laid in state. Mourners did not pay so much attention to the economic value of the cowries on funeral occasions. Alas, nowadays, because cantors are rewarded during performances (sometimes with handsome sums of money), the current Ghanaian cedi is highly coveted by dirge singers because of the great economic value attached to dirge performance in Dagaaba society as well as the urban centres where the art is also vigorously pursued. In the olden days, dirge singers also coveted money but their desire for money was not as great as what pertains these days among the Dagaaba and other ethnic groups. A group of Dagara elders who conducted research on cultural practices on funeral occasions in the olden days pointed out that money used during funerals was intended to support the bereaved family, the undertakers and other people who assisted the bereaved family in various ways. Rich people also took advantage of the situation to demonstrate their wealth in the way they supported the bereaved family. Such people felt at ease and were proud to do something good in the glare of the public.

\section{Genette's theory of structuralism}

Structuralist Theory argues that each narrative has two parts: the story itself (the content) and the discourse which actually refers to the expression by which the content is communicated (Chatman, 1978:19). In many of the narratives in the universe, there is an unlimited number of potentially perceptible relations. These relations could be of different kinds and orders including formal and thematic, synchronic and diachronic; casual and non-casual. Whenever these potentially perceptible relations become actually perceived, it is by virtue of some sets of interests on the part of the perceiver. Thus different relations among narratives will be perceived by anthropologists and anthologists, theologians and folklorists, literary historians and narratologists. Gerard Genette's (1972/1980, pp. 7-8) Narrative Discourse is a very essential piece of literary criticism which satisfies the urgent need for a systematic theory of narrative. It offers the basic constituents and techniques of narrative. Narratologist Gerald Prince (1973, pp. 7-8) proposes the notion of the 
narrator/narratee and equally suggests that the narrator speaks the narrative to someone whom he calls the narratee. He points out that the narratee is as important as the narrator. It is significant to stress that Prince's narratee can be dramatised inside the story as character-narratee. In a single narrative, there can be several narratees as can be several narrators.

On the other hand, Genette proposes various categories of narrative which cover Time, Mood and Voice. Genette's narrative structure suggests that the various categories and subcategories emphasise that the narrative is a complex structure in which a narratee is largely present in the various strata of the structure. One must note that Genette is concerned with the macrotext of the recit that is, the representation or ordering of events in narrative. Genette's category of time examines the various ways by which time may be organised in a narrative. Furthermore, he proposes three sub-categories of time: Order, Duration and Frequence. Time sub-category has two divisions as Analepsis and Prolepsis. The second sub-category of Time in Genette's macrotext is Duration which is the narrative pace; the speed at which the narrative moves. Duration has five sub-divisions: Pause, Slow-Down Scene, Scene, Summary and Ellipsis. Frequence is the third sub-category of Time. This refers to the fact that an event can either happen once or ' $n$ ' times and it can be told once or ' $n$ ' times. According to Genette, Frequence is the number of 'telling' of a particular event(s).

Secondly, Genette's major category of Mood deals with the one from whose point of view what is spoken in a narrative is seen. Mood is the point of view from which the narrative is presented. Mood basically represents Point of View of Narration. Mood has two sub-categories: Perspective and Distance. In terms of Perspective, Mood can be classified into three designations: Point of View, Narrator and Character. Distance in relation to Mood refers to how much or how little is told or how directly or indirectly. A clear distinction between Mimesis and Diegesis explains what Distance is in narration. Mimesis points to what is shown and Diegesis refers to what is told.

Voice is the third category in the presentation of events. Genette defines Voice as the narrative instance as opposed to the authorial moment. Voice has three sub-categories: Time of Narration, Narrative Levels and Person. All these three elements operate simultaneously in a narrative. In fact, Genette's Theory fulfils one of the most important achievements of what was known as Structuralism.

\section{Analysis of Dagaaba Folktales: Genette's Structural Models}

\subsection{Analysis Of Tale No. 1: Yeng-Gang-Naa}

In Kuwabong's (1992) collection of eleven Dagaaba tales, the first one is entitled "Yeng-Gang-Naa". It is a Realistic Tale based on the wisdom of a young boy whose cleverness superseded that of the Chief of Nanvilli village. The boy defied the order of the chief and named himself to the shock of his parents when he was only six days old lying in his cot. Moreover, the name contradicted the authority of the chief. The boy's name "Yeng-Gang-Naa" literally means "Wisdom supersedes a Chief". In Kuwabong's translation, it is rendered as "Cleverer than a King" which is also appropriate. The tale is woven around rivalry and retaliation between Chief Tamaa and his subject, Yeng-Gang-Naa. The tale begins with an abstract which can also serves as a kind of prelude to the story itself. Structurally, it is the introduction of the tale. Two major characters are introduced to the audience. Already, the audience can feel the emergence of the conflict of the tale that is, rivalry and contradiction between Chief Tamaa and Yeng-Gang-Naa.

With reference to Genette's Theory the tale is based on the distant past. Subcategories of Time emphasising Order, Duration and Frequency based on Genette's Theory can be applied in the interpretation and analysis of this tale. The main content of the tale is as follows:

Episode One: In the village of Nanvilli, there lived a wicked ruler known as Chief Tamaa. He ruled by draconian laws; thus his oppressed subjects were disgruntled about the abuse of hisauthority.Chief Tamaa decreed that all newly born babies were to be brought to him for naming.At the suburbs of the main village was a poor couple who bore a plump son.

Episode Two: On the sixth day of his birth, the boy questioned his parents where they were preparing feverishly to go.The wonderful boy advised his parents not to take him anywhere for naming and rather named himself Yeng-GangNaa to the shock of his parents.One day, Chief Tamaa heard a boy in the village address one of his (the boy's) colleagues as Yeng-Gang-Naa and he was alarmed and requested to see that boy named Yeng-Gang-Naa.Yeng-GangNaa was bold enough to request a cow from the Chief who out of malicious intention gave out one to the boy.

Episode Three: Earlier on, Yeng-Gang-Naa had received a bull as a gift from the shepherd boys whom he had fed with "zongkuoog" (millet fried and ground into flour normally served to farmers and shepherds).After five years, YengGang-Naa's cows increased to ten and he sent all to Chief Tamaa, first to return the bull given by Chief Tamaa and secondly, to thank him for lending it to him. Eventually, Yeng-Gang-Naa gave Chief Tamaa a bull and a cow.However, Chief Tamaa insisted on collecting all the nine cows to which Yeng-Gang-Naa agreed but planned to retaliate the chief's ingratitude.

Episode Four: At midnight, Yeng-Gang-Naa crept to a baobab tree that supplied Chief Tamaa with "tozOng" (fruit of the baobab used as a form of sugar/milk in sweetening foods) and used stones and other missiles in throwing at the fruits. When the chief heard the noise, he enquired who it was and Yeng-Gang-Naa disclosed he was the one. The seeds of the baobab were famous for the tasty "konton" (fairy) soup which was a delicacy prepared for Chief Tamaa.

Episode Five: Yeng-Gang-Naa revealed that his Father had just delivered a baby and needed the baobab fruits for him to savour.Chief Tamaa replied with a bluff that a man cannot deliver and as such Yeng-Gang-Naa was playing a damned sorcery game.Yeng-Gang-Naa replied with a cheeky question as to how Tamaa's bull was able to produce nine 
cows as the bull could not conceive to reproduce its kind.Upon hearing that argument, Chief Tamaa threw in the towel and returned Yeng-Gang-Naa's cows to him but planned another revenge on the prodigy.

Episode Six: Next, Chief Tamaa gave guinea-corn to Yeng-Gang-Naa's mother to brew as "pito" (local Dagaaba beer) the same day, an impossible feat to accomplish for it takes one to two weeks for guinea-corn to be processed and brewed into "pito". Yeng-Gang-Naa replied by sending pumpkin seeds to Chief Tamaa to sow that very day and make sure its fruits are turned into calabashes which Tamaa's guests will use in drinking the "pito" that Yeng-Gang-Naa's mother has been asked to brew.

Episode Seven: Chief Tamaa gave a bull smeared with shea-butter to his rival to graze in the sun without melting the shea-butter on its body.Yeng-Gang-Naa tricked the sun into his "bombo" meal and locked it up in a bag for three days during which the bull grazed with the shea-butter intact on its body.Chief Tamaa took his fat bull and vowed to punish his rival again.

Episode Eight: He ordered a pit to be dug in his palace after which Yeng-Gang-Naa was invited to a feast in the palace.Chief Tamaa ordered all his wives to brew hot-boiling "pito" to be poured over Yeng-Gang-Naa when he tumbled over the pit in the Chief's palace.Yeng-Gang-Naa got to know of the chief's trap and also dug a long tunnel to the palace from his house and linked the one dug at Chief Tamaa's palace.

Episode Nine: On the D-dayYeng-Gang-Naa agreed and sat on the chair through which he fell into the tunnel and ran fast home and informed his mother and she harvested the "pito" brewed by Tamaa's wives. Yeng-Gang-Naa invited chief Tamaa and his elders to a feast during which the Chief's wives' "pito" was served.

Episode Ten: Finally, after five years, chief Tamaa hatched the final plot to kill Yeng-Gang-Naa. He was sent on an errand together with the chief's eldest son across the Black Volta River.Chief Tamaa planned with assassins to waylay Yeng-Gang-Naa; thus, he persuaded the son to wear rags and Yeng-Gang-Naa was in complete regalia as a prince. Shortly before the messengers advanced their journey, Yeng-Gang-Naa persuaded the chief's son and they exchanged clothes with the chief's son now dressed as a true prince to befit his status.

Episode Eleven: The assassins killed the chief's son and Yeng-Gang-Naa rushed home and announced the death of the prince. At first, Chief Tamaa was celebrating Yeng-Gang-Naa's death but as the messenger got closer he realised that his plot had failed. Chief Tamaa confessed all his wickedness for the past 36yrs and abdicated his throne. Thus, YengGang-Naa was proclaimed the true and loyal Chief of Nanvilli for his personality and character matched the name he bore: Yeng-Gang-Naa. The conflict of the tale is obvious from the first and second episodes. The tale is preceded by a kind of prelude which introduces the tale as a popular one among the Mole-Dagbani peoples. Most Dagaaba children are supposed to know this story as it is frequently narrated among them. Kuwabong(1992) points out that this particular tale is often used to begin folktale narration sessions or end these sessions.

Whilst this pertains to Manlaali speakers of Nadowli, Kaleo and Charia and their surrounding areas of north-western Ghana, the people of Nandom use riddling sessions to begin folktale narration sessions. It normally takes the form of a Call-and-Response as in the following illustration:

Ni lobr, nilsbr ... Tell them, tell them (riddles).

So kuos be yi ... Taken a bath but not so clean

Zc kaa be ta ... Partially rubbed body with pomade

Ba-kpagl ni nyie... Dry valley-side farm produces plenty yam.

Ba zulu ni zume... Deep river with plenty fish

Ka-gbou ni kyi ... Plenty millet signifies bumper harvest.

Gabili ni tug ... A shrub of small ebony tree

Burmwaa gbe-gang ... Burmwaa (kind of mysterious bird) with a broken leg

Kpankpole ni nuur... Featherless chickens signify plenty fowls.

Bibiir ni gure ... Now children, here come the riddles!

This second illustration serves as a prelude to a story-telling activity itself. It is normally initiated by the first narrator of folktales for an organized audience.

One Member of Audience: "N ku n naab”... I slaughter my cow.

Any Member of Audience: "N ir a nyaa"... I choose the chest.

Same Member of Audience: "N leku n naab” ... Again, I slaughter my cow.

Any Member of Audience: "N ir a gber ... I choose the leg.

Same Member of Audience: "N leku n naab” ... Once again I slaughter my cow.

Any Member of Audience: "N ir a puor" ... I choose the stomach.

Same Member of Audience: "N leku n naab”... Again, I slaughter my cow.

Any Member of Audience: "N ir a nyage" ... I choose the intestines.

Same Member of Audience: "N leku n naab” ... Once again I slaughter my cow. 
First Narrator as Member of Audience: "N ir a zu ... I choose the head.

The above illustration is the commonest formula used as a prelude to a folktale narration session. When the audience does not know the answer to the riddle or when a wrong answer is given, then a member of the audience accepts the fact that they have all been bamboozled by the riddle and then says "de fu naa" (indicating, we don't know the answer). It is important and equally fair for most people to be offered the chance to give the answer to the riddle to avoid monopoly by some few people.

The entire folktale has fifteen episodes. These episodes are interspersed with only one interlude and two songs. (Kuwabong, 1992, pp. 2, 3, 8 and 9) The gossip of Chief Tamaa's First and Second Wives about his Sixth Wife is in the true sense not part of the real tale. The two songs reiterate the theme of contradiction of the two major characters, Chief Tamaa and Yeng-Gang-Naa. The first song on page eight (p. 8) is a complete irony because it was not the death of Yeng-Gang-Naa that Chief Tamaa was celebrating but rather his own son whom Yeng-Gang-Naa had tricked which resulted in the dismal death of the prince. Yeng-Gang-Naa's intuition and wisdom enabled him to deceive Chief Tamaa's son thereby reversing the order of events. The conspiracy made by Chief Tamaa and the assassins is an obvious situation of prolepsis because the Chief was certain about the imminent death of Yeng-Gang-Naa. Death occurred later even though that was not the death of Yeng-Gang-Naa. The second song on page nine (p. 9) is the climax of the tale. The song does not only reveal the themes of jealousy, rivalry, contradiction and treachery between a ruler and his subject but also serves as a Confession on the part of the defeated villain-Chief who had failed woefully in his plots against Yeng-Gang-Naa. Moreover, apart from the Confession, Revelation of the power of Yeng-Gang-Naa's wisdom is clearly juxtaposed against the wicked, senseless Chief Tamaa. The tale does not only reveal how great YengGang-Naa is as a major character but also a complete liberator of despotism. This leads the audience to a situation of "Anagnorisis". Truly, he lives up to the meaning of his name, Yeng-Gang-Naa, a feat that stands unrivalled in the land of Nanvilli which was governed by Chief Tamaa as a wicked ruler.

Additionally, there are several interesting aesthetic features of the narrative language of the tale. The narrator is frank in the use of words and the major strengths of the tale rest on a couple of hyperboles some of which can be identified on pages 2, 4, and 7. The first hyperbole can be identified in the Second Episode. It would be recalled that after YengGang-Naa had shocked his parents by naming himself, they felt spellbound and that amazement is represented in the following words: "One cannot describe the consternation that seized the hearts of the parents. To put it crudely their asses were hot and wide open that one could roast a tuber of yam there". (Kuwabong, 1992, p. 2) The effectiveness of this hyperbole underscores the apt description of the fear and awe that seized Yeng-Gang-Naa's parents as their child shocked them by speaking on the sixth day of his birth and even going further in naming himself. This exaggeration is supposed to captivate the attention of the audience. They experience shock and surprise and that mood corroborates the same mood Yeng-Gang-Naa's parents demonstrated earlier. The narrator's words are apt and they create a deep sense of humour aimed at embellishing the events of the tale.

The next example of exaggeration is reference made to the setting sun as we often observe on clear and sunny days. When wicked Chief Tamaa gave guinea-corn to Yeng-Gang-Naa's mother to brew "pito" (local beer of the Dagaaba) and serve the drink the same day to his guests, the poor woman saw that it was impossible to accomplish the chief's demand. This was because at least two weeks are needed to process the guinea-corn into malt before it is ground and brewed to produce pito. She pleaded with the chief to give her enough time but the Chief refused to do so. Rather the angry Chief retorted to her plea and said: "Get off from my sight woman, miserable wretch that you are. I want the pito by the sun's red anus or else you and that rogue of yours called Yeng-Gang-Naa will smell pepper”. (Kuwabong, 1992, p. 4) The personification of the sun with a "red anus" reveals the beautiful nature of the setting sun which ironically too, marks the rapid disappearance of daylight. As nature has it, the signs of the setting sun demonstrate the amber colour with sprinkled light rays across the western part of the sky. The vulgar term "red anus" reiterates the beauty of the setting sun as it comes into contact with various aspects of nature such as rivers, seas, hills and mountains. The literary aesthetics of exaggeration reinforces Chief Tamaa's urgent call for "pito" from the poor woman whose task could never be accomplished by the close of the same day that she got the guinea-corn. Indirectly, Chief Tamaa was warning the woman that time was fast running out. That smacks of an open wicked threat! That threat was in line with the last two words uttered by the desperate Chief - "smell pepper" which suggests an urgent but ungovernable situation that YengGang-Naa's mother was confronted with. The context under which those words were uttered tells the audience that Chief Tamaa was desperate, wicked and insensitive.

The final example on the significant use of language in the tale is directly connected with Chief Tamaa's conspiracy with the assassins to murder Yeng-Gang-Naa. Chief Tamaa ordered that Yeng-Gang-Naa should be given the best clothes to put on consisting of colourful smocks. Additionally, he was given a "strong ebony-black stallion" to ride. Ironically, "the chief's son was given rags and a constipated donkey that let off "volleys of foul air with every step" (Kuwabong, 1992, p. 7). This Episode does not only reveal prolepsis (Chief Tamaa's anticipation of Yeng-Gang-Naa's death as well as the anxiety of the audience about it) but it also represents complete contradiction and reversal of the normal order. In a reasonable human society nobody can dare humiliate a prince that way. Yeng-Gang-Naa read the despotic Chief's mind carefully and quickly reversed the situation to the normal order. This supposed humility of the prince dressed in rags underscores the significance of disguise for good reasons. The Chief's plot backfired. The natural order of Aristocracy was reversed and the disgusting portrayal of Tamaa's son was a timely bomb and trap which exploded and caught Chief Tamaa's son and Tamaa's own conscience. Peripeteia occurred when a reversal of the conspiracy fell on the Prince instead of Yeng-Gang-Naa. The saying, "The evil that men do lives after them" 
summarises the significance of the narrative language depicted in Episode 12. The Episode reveals the importance of plot (scheming, conspiracy) in human history. It sounds ridiculous to find a king turn plotter against a poor, insignificant subject he has complete control over in his kingdom.

In Genette's Theory Time's subcategory of "Duration" can be used to explain certain portions of the tale from the Opening of the tale until the Epilogue. From the Opening of the tale, the audience gathers the idea that the despotism of Chief Tamaa had persisted for a long time: "Any open sign of protest (from his subjects) was met with brutal repression. This went on until the twentieth year of his enskinment" (Kuwabong, 1992, p.1). The duration of time referred to here can be viewed as a situation of analepsis. The narrator wants the audience to know that Chief Tamaa's despotism had persisted for far too long. Despite that the supposed ruler had not changed from his wicked ways. Another instance of duration is reference to the number of months that Yeng-Gang-Naa's parents had been married. It was just one year three months simply termed by the narrator as "in the fifteenth month of their marriage" (Kuwabong, 1992, p. 1). The sixth day on which Yeng-Gang-Naa sat up in his "cot of reeds" and questioned his parents about their feverish preparations to go somewhere, also reiterates the topsy-turvy nature of human development. This First Episode of the tale sets the right tone of the conflict which is full of twists and turns. It explains the situation of wonderment which leads to deception, treachery and betrayal on the part of the major characters. Yeng-Gang-Naa is something of a prodigy whilst Chief Tamaa is just a clever fool who is often outwitted before he completes his conspiracy. A good and an honourable leader should attract homage and respect automatically from his subjects. A good leader is supposed to be an epitome of commendable governance and not extortion and deception. Eventually, Chief Tamaa confesses and regrets ('Harmatia') his wicked deeds. He accepts the fact that there are good and bad rulers. His abdication is a shameful acceptance of his foolishness, treachery and despotism. This act is a complete 'anagnorisis' as the audience see that the arrogant chief has realised and acknowledged the plain truth about the wisdom of Yeng-Gang-Naa who has lived up to the expectation and confirmation of the name he bore. Yeng-Gang-Naa was indeed wiser than Chief Tamaa. Chief Tamaa is a good example of a bad ruler. His subjects rather fear and dread him instead of paying him homage and honour.

\title{
5.2 Analysis of Tale No. 2: "How Orphan Brought A Prince Back To Life"
}

The second tale is also examined as follows: Tale No. 2 entitled "How Orphan Brought a Prince Back to Life" is a typical example of a Pourquoi or an Etiological Tale in which humans and animals interact. It was narrated by a 32 year old man; a farmer from Nandom-Dumagye. The context was a folktale narration session on Radio Foundation for Rural Education, Empowerment and Development (FREED, $92.3 \mathrm{FM}$ ) programmes on culture transmission and dissemination. The audiences were five people in the studio, the author of this paper as well as Radio FREED listeners. The date and time of narration were Sunday, 25 January, 2015, 7pm-8pm.

\subsubsection{Narrative Structure of Tale No. 2: "How Orphan Brought a Prince Back to Life"}

The tale is made up of seven main episodes. These episodes are closely linked with the characters and the major themes which can be easily be identified. The Opening Formula is according to Dagara tradition of folktale narration. The narrator preceded the performance with the most popular song often used to demonstrate that a serious business of folktale narration is about to begin. The song is as follows:

\author{
$\mathbf{N}$ baa be nyəg wala $\varepsilon, \ldots$ My dog failed to catch a deer \\ $\mathbf{N}$ baa be nyगg wala $\varepsilon, .$. My dog failed to catch a deer \\ N baa be nyəg wala ... My dog failed to catch a deer

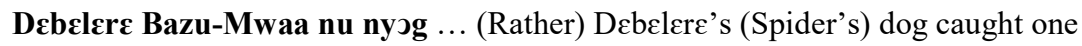 \\ $\mathcal{E}$ wa yang Kulkpaa kparame ... Unfortunately, Kulkpaa has been driving and harassing me about \\ Kulkpaa teru be, ... Kulkpaa, persist in your harassment \\ Kulkpaa teru be, ... Kulkpaa, persist in your harassment \\ Nyine na Bazu-Mwaa pag nuor, ... Where is that capability of a dog with a stunted head to achieve \\ such a feat?
}

After the song, the riddling session followed leading to the real performance of the tale. The narrator prompted his audience on the major characters of the tale by stating categorically "The tale I am about to narrate focuses on Leper, an Orphan and a Chief. The researcher noted that the "Once upon a time" fashion was also employed by the narrator who said "Many years ago, since time immemorial, a certain man and his wife gave birth to their child and later on died and left behind the child as an orphan". This set the right tone for the performance requesting the audience to cast their minds back several years ago, long before they were all born.

\section{Summary of Tale No. 2: "How Orphan Brought a Prince Back to Life"}

Episode One: A certain Chief volunteered to cater for the Orphan and sent him to his palace. In the palace, there was also a Leper under the care of the Chief as well. at first, Leper and Orphan collaborated harmoniously and worked together in peace. This harmony did not last as persistent theft cases in the palace were attributed to Orphan. As a result of this, Orphan was evicted from the palace. 
Episode Two: Orphan endured so much pain after the eviction. He wandered and eventually established a cottage in the thick forest where he found a plain-looking area. Not long afterwards Monkey, Ant and Cobra came across his settlement one after the other and Orphan agreed to co-habit with them.

Episode Three: One day, the Chief sent Leper to look for termites to feed his chicks. Leper went to the forest and discovered the abundant harvest Orphan had made and reported the remarkable prosperity to the Chief. Obviously Orphan's outstanding harvest had surpassed that of the Chief. The Chief roused himself and inspected 76 of his granaries to reassure himself he was still the wealthiest despite Orphan's remarkable success. To his utter shock, termites had ravaged all his stock and he was short of words and ideas.

Episode Four: Therefore, Leper suggested to the Chief to call Orphan and order him to restore his lost stock. Thus, began the test of Orphan's patience and endurance. First, Orphan was asked to sort the millet that was mixed with the soil as devastated by the termites. This awful task was easily accomplished by Orphan through the generosity and act of charity from Orphan's household mate, Ant who brought all his family members and sorted the millet out as the Chief had ordered. When day broke, the Chief was delighted with the news that Orphan had accomplished the task.

Episode Five: One day, the Chief relaxed outside the palace under a giant baobab tree. A ripe fruit fell down and he tasted the white substance and realized that it was sweet. As he wondered how to harvest the rest of fruits on the tall tree, Leper suggested again, he should order Orphan to harvest them. When Orphan reported and was given the unbearable task, he wept on his way home. Monday discovered his misery and volunteered like Ant, went in the middle of the night as there was moonlight and harvest all the ripe fruits. Thus Orphan had surmounted ordeal number two by courtesy of Monkey.

Episode Six: In the Chief's Kraal was a tough-looking bull. The Chief once again ordered that it should be killed without the use of a club, stick or knife. As usual, the Leper at the Chief's palace prompted the Chief to order Orphan one more time to kill the bull without any weapon. Orphan's misery was discovered by Cobra who agreed to help him. Orphan arranged with Cobra to hide in the shrubs and requested that the bull be driven into the bush. Cobra gave a sharp bite and the bull collapsed dead. Cobra gave Orphan sound advice whenever the Chief's son (the Prince) died as a result of the eating of the poisoned beef. At midnight, disaster stuck the palace and Chief's son died as predicted by Cobra. Meanwhile, as the people waited throughout the night, Orphan and his neighbours just relaxed and waited until the following day early in the morning.

Episode Seven: When Orphan went to sympathise with the Chief, the hypocritical Leper prompted the Chief once more that Orphan had arrived. Without delay, the Chief ordered Orphan to restore his son's life. The Chief emphasised "If you don't resurrect him, I will also kill you"'. Orphan touched the corpse and stood in deep thought, he finally disclosed that one more thing was required. The Chief vowed to provide whatever he requested even if that was the supposed teeth of a nocturnal bird, Owl. Orphan stunned the Chief by asking for the lungs of a Leper as the only essential thing that could bring back his son to life. It was then that Leper sensed danger and enquired in anxiety whether it was the lungs of a dead or a living Leper that were needed. His own wickedness had caught up with him. There was no response from anybody and the Chief ordered that Leper be killed and his lungs were used in reviving the Prince. Mischief and hypocrisy do not pay; the only payment is retribution.

From the above summary, there is evidence to prove that this tale is compact in structure, interesting and highly didactic. The themes of hypocrisy and wickedness expose similar conditions in human society. The interpretation of this tale can be viewed in various lights. First, it reveals the importance of love, solidarity and tolerance. Leper failed to tolerate Orphan and used mafia tactics to cause Orphan's unlawful eviction from the Chief's Palace where both of them had equal privileges to share. Secondly, this tale reveals the commendable solidarity between Orphan and Monkey, Orphan and Ant and Orphan and Cobra. Orphan had kept the principle of tolerance quietly in his heart when he was evicted from the Palace. This explains why he accepted Ant, Monkey and Cobra to come and stay with him in his new settlement.

The envious and mischievous Leper who discovered it later, tried to extend his tentacles of wickedness and favouritism but failed. His boot-licking attitude persisted but it finally had a boomerang effect on his life and wickedness. The moral lesson the tale teaches people is "A Talebearer suffers a miserable end/fate. The true character and personality of both Orphan and Leper are clearly juxtaposed episode after episode. The Leper ignored the fact that it was heartless to aggravate the already precarious situation of Orphan. The cry of the poor is often heard by God. The components of this tale which make it a unifying whole are the following: The systematic organization of the Episodes. The seven episodes closely link up the characters, the events and the major themes of endurance, pain, tale-bearing, love, solidarity, hypocrisy and retribution. The Opening Formula is apt and according to the recognized Dagara tradition of folktale narration. The third point worth considering is the role and significance of songs used before or during folktale performance. The preceding song tells the audience something about the past-time of hunting among the Dagara of northwestern Ghana. The song reveals certain interesting characters both human and animal in nature. First, the word "N" (My) prompts the audience to infer that reference is being made to the hunter. The second character, in order of occurrence is the dog ("baa") an animal, followed by "wala" (deer) another animal. The fourth character is the famous

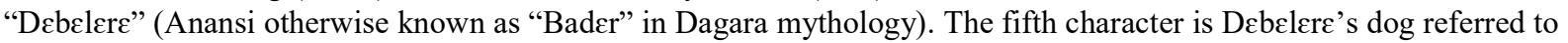
here as "Bazu-Mwaa" (Dog with-a-Stunted-Head). The sixth character and final one is a rather mysterious one simply known as "Kulkpaa" who appears to be more powerful than Debelere's dog with a stunted Head. The song equally reveals failure and success on the part of the hunter's dog and Debelere'sBazu-Mwaa. Persistence and failure can be 
seen in the tale on the part of Leper. Perseverance and success can be associated with Orphan who ended up vindicating Leper's wickedness and mischief.

\subsubsection{Narrative Language of Tale No. 2: "How Orphan Brought a Prince Back to Life"}

The opening of the tale reveals to the audience that the narrator has used analepsis in beginning the development of events. Reference to "many years ago, since time immemorial, a certain man and his wife gave birth to their child and later on died and left the child as an orphan" supports the basis of the analeptical style that Genette emphasises in his Narrative Model. The Model covers Time, Mood and Voice. Time's subcategories are three in number: Order, Duration and Frequency. Time's subcategory of Order has two sub-divisions: Analepsis and Prolepsis. Depending on the nature of the tale, the researcher will present the analysis in diverse ways but all analyses will cover Genette's narrative model made up of Time, Mood and Voice. These three broad models are further subdivided to facilitate understanding of their application in folktale analysis.

It is in this light that Time's subcategory of Order plays an important in the exposition of Tale No. 2. The eviction of Orphan from the Chief's Palace underscored proleptic undertones in various ways. One needs to dilate on some of these. The tests and endurance Orphan went through represent the importance of Prolepsis in the nature of the events as they occur in the tale. In prolepsis, a piece of information in a story may be moved forward several times. In fact, interior flash forwards are advanced pieces of information of later point in the story, sometimes in anticipation of an event and sometimes as advanced narrative of what will be told later. Several flash-forwards occur in most of the tales that were collected by the researcher. In Tale No 27 involving how an orphan brought a Prince back to life, one can easily identify three situations of interior flash-forwards based on the feats Orphan achieved through the support of Ant, Monkey and Cobra. The first test of endurance was when the Chief asked Orphan to separate millet from the soil when his 76 granaries were devastated by termites.

Leper had instigated the Chief to punish Orphan with the conviction that Orphan was going to fail. However, Orphan's success in surmounting that uphill task was already accomplished in advance because Orphan had accepted Ant to establish his home close to Orphan. If he had rejected Ant, Orphan would not have been able to sift the millet from the soil. Therefore, Orphan's success in that first test was a foregone conclusion. The same thing applies to the plucking of the ripe baobab fruits by Monkey to help Orphan surmount the second ordeal handed down by the Chief. Monkey's dexterity in climbing trees was accessible to Orphan who had helped him earlier on by tolerating Monkey and accepting him to settle close to Orphan's home. The killing of the bull by Orphan through Cobra is another significant event depicting the importance and relevance of interior flash-forward in Tale No. 2.

It would be recalled that before Ant, Monkey and Cobra helped Orphan accomplish the herculean tasks handed down by the Chief, they had already planned with Orphan long in advance, as to what to do in order to save Orphan's face. All these are proleptic in nature. The most astonishing one was the magical revival of the Prince back to life after the Chief and his family had consumed the poisoned beef. Cobra planned with Orphan to accomplish the final task and end the terrible ordeals that were visited on him in succession. He told Orphan to demand the lungs of a Leper which compelled the Chief to have Leper killed to save the life of his beloved Prince.

Another significant thing about Time Order in Tale No. 2 is the adequate supply of background information on the main characters such as the Chief, Leper, Orphan. All other characters such as the Prince, Ant, Monkey, Cobra and Orphan's deceased parents revolve around them. One can even do one on one mapping as the Chief can easily be associated with Leper, Orphan and the Prince. On the part of Orphan, Ant, Monkey and Cobra are easily associated with him. The association of the Prince and Orphan is equally important even though Cobra has to take all the credit that he more than deserves. Orphan miraculously revived the dead Prince. The striking difference of these two characters is underscored by the wealthy rosy and pleasant background of the Prince. An Orphan is the most vulnerable person in society. Ironically, the endurance and the magical powers of Orphan (whose background is miserable) are responsible for the revival of the dead Prince. These two characters seem to be diametrically opposed. All the above characters are homodiegetic persons who appear in various ways repeatedly as the events occur. Those who actually come into sharp focus are Leper, Orphan and Cobra. Without them, the tests, endurance and final revival of Prince would not have taken place.

The tale teaches the audience on the nefarious effects of tale bearing activities and the devastating effects they have on society. The law of retribution easily catches up with wicked people who delight in inflicting pain on even the most vulnerable people in society. The didactic nature of the tale equally reinforces the personalities of the various characters. Leper is poor and miserable but he has no sense of humility and sympathy. The narrator's comments reiterate why Ants, Monkeys and Cobras behave in the way they do. The narrator's own words sum up everything for the audience: "that is why when we cultivate our farmlands, Ants come to take some of the crops. Ants are therefore not thieves. They have helped to enrich us. (Even) before our maize and groundnuts mature, Monkeys visit our farms and destroy them. They have a portion in our farm produce. When you see Cobra catching fowls in our homes, it means we all share the same property." It is these final words which summarise the etiological nature of the tale.

The vocabulary in the tale also deserves close attention, Debelere's dog is called Bazu-Mwaa (literally, it means "shortheaded dog"). The short-headedness is a peculiarity which marvels the audience. Though the head of the Debelere's dog is stunted, it was able to catch no small a creature than a deer. The least could e expected of Bazu-Mwaa in terms of achieving feats in hunting expeditions but Debelere's ugly-looking dog was able to spring a surprise. Appearances are certainly deceptive. The next character in that introductory song is "Kulkpaa", a non-human being who struggled with 
Bazu-Mwaa as a result of hunting in his territory. Kulkpaa is a god of the wilds (forest) and is bound to attack anybody spiritually for daring to hunt in his territory which is out of bounds to hunters. Unknowingly, Debelere's dog BazuMwaa caught a deer in the forbidden territory. Initially, Kulkpaa attacked the hunter as he had a dog too but the Hunter might have tried to exonerate himself from the taboo that was broken and infuriated Kulkpaa leading to his attack. The Hunter then sang the song to prove his innocence and pointed at Bazu-Mwaa as the culprit. Upon hearing from Hunter, Kulkpaa turned round and attacked Debelere's Bazu-Mwaa and Kulkpaa perhaps to the delight of the Hunter hence the latter part of the song "Kulkpaa just persist in your harassment” (of Bazu-Mwaa instead of the Hunter).

In fact this preliminary song is a whole tale in itself even though short in nature. One therefore sees this struggle initiated through this song, replicated in the tale itself as Leper and Orphan struggle against each other. One could liken Kulkpaa to Orphan and Leper to Debelere's Dog, Bazu-Mwaa. Just as Bazu-Mwaa had angered the forest god Kulkpaa, Leper too had bitten more than he could chew by the persistence of his wicked behavior towards Orphan. Now that Cobra had shown Orphan what to do to revive the Prince and request was made to use a Leper's lungs for the medicine, Cobra too like the Hunter could have stood by singing a song retribution visited against the wicked Leper.

Following the eviction of Orphan from the Chief's Palace, he wandered about in thick forest in the middle of which a plain-looking area where he built his settlement known in the traditional Dagara language as "gur". The term suggests several meanings. It therefore can be interpreted in several ways. The term could refer to a cottage established in a lonely remote area where human activity is minimal. The term "gur" also suggests the forlorn nature of Orphan. Thirdly, it could also refer to the hut-like nature of Orphan's settlement. In this case, the physical features of the house are brought into focus. The term suggests an apt description of the humble and the modest nature of Orphan's settlement.

Initially, Orphan's life was miserable as he was persistently accused of theft at the Palace resulting into his unjustifiable expulsion. Orphan was oppressed and despised in his society characterised by jealousy and discrimination as shown by Leper. Orphan established an independent cottage. Orphan was kind and sympathetic enough to accept and tolerate Ant, Monkey and Cobra who requested to stay with him.He established a farm which yielded a bumper harvest and created a success story which was reported by Leper back to the Chief who had expelled him from his Palace.Orphan's success in life aroused jealousy and discomfort for the Chief as 76 of his granaries were devastated by termites. He was misled to hand down four difficult tasks which Orphan persevered and accomplished using his wisdom. The most outstanding feat Orphan accomplished to the delight and amazement of the Chief was the restoration of the dead Prince back to life. Thus, Orphan is not only a symbol of success but also hope to all those who are maltreated and oppressed by the most dominant in society.

The moral lesson reveals the pathetic fate of tale-bearers, boot-lickers and hypocrites. Leper's life was characterised by persistence and failure whilst that of Orphan was characterised by perseverance and success. His resilient character ended up vindicating Leper's wickedness and mischief.

\subsubsection{Paralinguistic Features Employed in Tale No.2}

Paralinguistic features that are associated with the tale are the following: The calm and collected nature of the narrator throughout the presentation/performance. He was eloquent and confident with his delivery. He had an audible and captivating voice. The researcher was particularly drawn to his confidence in the performance. He adopted a chronological style and what was supposed to be said at the beginning till the end was done in a professional manner depicting the art of Dagara oral performance. The narrator's voice modulation with reference to the description of certain things and events was apt. The narrator used the term "gur" to describe the cottage that Orphan had established on his own. That was typical of a village settlement where the idea of being remote is suggested. Throughout the narration the narrator maintained eye contact with the audience in the studio. The narrator did not throw his arms frequently but used his voice much more effectively. His facial expression indicated that he was enjoying the performance which equally attracted the audience. Additionally, the performer knew how to tell the tale using the right skills to accomplish his task.

\subsection{Analysis of Tale No. 3: "Orphan And His Faithful Friend Guinea-Fowl"}

The third tale that was examined in this study could be summarised as follows:

Episode One: A child lost both parents and the maternal uncle He was left him without anybody to take care of him. Everyone was rich whilst the orphan was poor. He moved out of the village and established a cottage there. He cultivated a limited portion on a small hill part of his arable land and depended on subsistence farming. One day, the Chief sent his children to the bush to steal any guinea-fowl they could find anywhere.

Episode Two: The children chased one guinea-fowl into Orphan's house. Orphan caught it and quickly hid it under a large earthenware pot. When Orphan was questioned about it, he denied and said he had not seen any guinea-fowl. Despite his response, the chief's children went inside Orphan's house and searched everywhere to no avail. After their departure, Guinea-Fowl asked Orphan about his background and he disclosed it. Guinea-Fowl had pity on him and pledged to help also him become rich.

Episode Three: Guinea-Fowl cut an ebony stick and made three stripes on it to produce a magic wand. The stick was striped with white, brown and black colours. Orphan used the magic wand effectively and changed all the Chief's black cows into white ones and created his own kraal. 
Fourth Episode: An alarm was raised on the disappearance of the Chief's cows. Orphan was accosted and queried about the source of his wealth. He responded, "It is God who has given them to me". The Chief asked a search party to conduct an investigation.

Fifth Episode: A traitor known as Gegera (Tale-bearer) visited Orphan and pretended to be a true friend. Gegera lured Orphan to a 'pito' bar and intoxicated Orphan so that he could reveal the secret of his wealth to him.

Sixth Episode: God removed sense of caution from Orphan and he disclosed the secret of his wealth to Gegcra who visited him again. Gegera secretly excited about knowing the secret and rushed and told the Chief.

Seventh Episode: Orphan confessed to Guinea-Fowl that he had unconsciously disclosed the secret about his wealth to Gegera. He reassured Orphan that he was capable of resolving the matter. Guinea-Fowl gave Orphan further instructions saying, "When anybody comes to pick you up for trial at the Chief's Palace do not worry at all". However, when you get closer to the Palace use the brown part of the magic wand and touch him and he will turn into a donkey at once. Unfortunately, Gegera was sent to pick him up amidst fears and anxiety on the part of Orphan.

In the final Episode (Eight) which ends the tale, Gegera came and told Orphan that the Chief wanted to see him at the Palace. When they got closer to the Palace, Orphan used the brown part of the magic wand and touched Gegera who turned into a donkey. Orphan disclosed that he had received summons to report at the Palace. The Chief asked him to go outside and bring in the one who had brought the summons as nobody speculates in court. Witnesses are needed to give evidence. When Orphan got outside, he saw a donkey at the back of the house neighing saying: "Maanu, Maanu, Maanu" meaning, "I am the one, I am the One, I am the One". Orphan returned to the Palace and reported to the Chief that he had not seen anybody but only a donkey standing there and neighing constantly. The Chief discharged Orphan and said that legal cases in court are backed by facts, evidence, witnesses and not mere hearsay.

The early life of Orphan was characterised by misery. He was the poorest person as he did not ("kpagnyuu" literally, "develop a lumpy neck" that is, he was not wealthy).He developed a defensive mechanism for life and saved the refugee Guinea-Fowl from capture. In reciprocation, Guinea Fowl devised a magical wand and gave it to Orphan. Orphan used the magic wand and changed the Chief's cattle from black to white magically. Gegera intoxicated Orphan and he revealed the source of his wealth. This was reported to the Chief and Orphan was queried. He responded by saying that it was God's providence.

Orphan confessed to his faithful friend, Guinea-Fowl that he had unconsciously disclosed the secret about his wealth to Gegera (Tale-Bearer). He reassured Orphan that he was more than capable of resolving the matter. Orphan used the brown part of the magic wand and touched Gegera (Tale-Bearer) who summoned him to the Palace and he turned into a Donkey. At the Palace, Orphan was asked to bring in the one who had summoned him. Upon returning, he reported to the Chief that he had not seen anybody but only a Donkey at the back of the house neighing and saying: "Maanu, Maanu, Maanu" (meaning "I am the one, I am the one, I am the one"). It was Gegera who had turned into a donkey and there was no prosecutor to provide evidence against Orphan. Therefore, the Chief dismissed the case.

Thus, Orphan was smart and wise to evade prosecution. The malice Gegera had against him was cleverly averted. Orphan's obedience to Guinea-Fowl yielded positive results as he became rich overnight. Orphan's humility and hospitality attracted him towards Guinea-Fowl whom he protected against his pursuers. Generally, Orphan's life was marked by steady progress. He was accommodating and innovative and his life was eventually crowned with success. His humiliation had ended.

\subsubsection{Narrative Structure of the Tale No. 3: "Orphan and His Faithful Friend Guinea-Fowl"}

Structurally, this folktale is a typical example of a magic tale because of the use of magical elements such as the two wands that Guinea-Fowl produced for Orphan. Both sticks produced wonders as black cows were turned into white cows and the second magic wand turned Gegera (one of the main characters) into a donkey when Orphan used it to touch him. The last episode is obviously the climax of the story. Orphan escaped narrow conviction at the Palace when Gegera turned into a donkey that could not speak as humans do. However, its neighing gave evidence that it was the one that had gone to summon Orphan to court with the utmost conviction that Orphan was going to be charged and found guilty. In a twist of events, that was not to be. As Gegera had turned into a donkey, evidence against Orphan was sealed and the case could be heard as there was no witness and no evidence to work with.

Even though the tale has magical elements, most of the events depict certain true things about human life and as such it can be regarded as a Realistic Tale. Events which are true to human life include the idea of being orphaned, the struggles made by Orphan to survive in a rather difficult world and the Chief sending his children to hunt for a guinea fowl. The pastime of hunting is still practiced and there are a lot of tales associated with this. Another realistic feature about human life is tale-bearers who betray people and cause a lot of trouble in society. Gegera (somebody who is a traitor and a tale-bearer) is a suitable illustration in the tale Gegeri (plural of Gegera) can turn lack into white as they are good at propaganda. They disrupt peace in families and communities by their nefarious activities. It is therefore not surprising that Orphan is betrayed and summoned to the traditional court. Gegera's excitement about doing the Chief a favour is short lived as he is caught in his own web of destruction. Before the case was heard, the tables turned; Gegera is prevented from inflicting more pain in the life of Orphan. By the sudden turn of events, Gegera was rendered nonhuman and the case was closed in court as there was no witness to convict Orphan. 
The narrator was articulate in words and reassuring in composure and his application of histrionics in the performance of his tale. He spoke with confidence and easily delineated the facts of the tale. His mode of delivery was fast but pleasant and appropriate to the audience and the general understanding of the tale. The narrator used voice modulation suitably throughout the performance. He was equally conscious about indicating transition. The sixty-one year old male farmer created humour throughout the performance. That technique created the requisite excitement in the audience who equally played an active role. The narrator captivated the attention of his audience as the tale was greeted with approval and applause. The audience were not only attracted by the narrative skills of the narrator but were equally amused by the obvious moral lesson derived from the tale.

The researcher was impressed with the narrator's comments about the entire tale. These comments were useful to the audience and even enhanced the understanding of the tale. His description of Gegera (traitor, tale-bearer) now turn Donkey, is vivid enough to the audience as well. For instance, he said,

"As you see the donkey, it is a human being. It understands the Dagara language. (You) see the way Donkey demonstrated bravery and courage. Its courage is that of a man and its anus represents the sexual power that a woman has. However, it is a traitor. That is why it understands human speech. For instance, if you take a donkey somewhere to do some work and you try to redirect it to go elsewhere it won't go because it is a thief". (Tale No. 3, Narrated by a 61 year old male farmer from Nandom-Taayaga, 20th November, 2015)

\subsubsection{Narrative Language of the Tale No. 3: "Orphan and His Faithful Friend Guinea-Fowl"}

Generally, the narrator's language was simple and down to earth. He did not use any complicated expressions to befuddle his audience in any way. Some of the words and terms he used to enhance his narration included "gur" (a cottage farm), "maanu" (I am the one) and "deblu" (bravery and courage). Contextually, these words were used appropriately. "Gur" was mentioned by the narrator when he outlined the circumstances leading to the establishment of a cottage by Orphan who was virtually regarded as an outcast in his community. The narrator indicated that all the people of Orphan's village had lumps on their necks and he was the only one who did not develop one. Therefore, he felt uncomfortable and left for an isolated place where he established the cottage. The term "gur" signifies subsistence a portable and manageable piece of arable land. As Orphan was alone with no helper he had to do what was within little means in order to earn a living. Gur also represents a land of independence and not dependence as people looked down on Orphan in the village.

There is another term, "Kpag nyuu" (had a lump on the neck) which is an idiomatic expression meaning wealthy. In fact, some kind of luxury that one can associate with village life. Orphan was helpless because both parents were no more. As a result, he did not develop a lump on his neck (he was not rich) and could not be pampered by anybody. He was therefore miserable and humiliated by others. These circumstances compelled him to establish a cottage farm ("gur").

When the Chief's children went on a hunting expedition and chased a particular guinea fowl to Orphan's house, he quickly protected the "refugee" with an earthenware bowl/pot. "A bikpieb nyog vobli laa" (Orphan caught it and hid guinea fowl under an earthenware bowl/pot). The term "nyəg vobli laa" is significant to the kind of protection that Orphan had given to Guinea-Fowl. It signifies that the vulnerable and the endangered deserve support and protection from the aggressive and arrogant oppressor. Though the Chief was wealthy and had many cattle he did not want to touch any of his animals for his own sustenance. He felt that it was better to extort the little property of the vulnerable in his society. Thus, he instructed his sons to go all out and steal any guinea fowl that they saw. Fortunately, the desperate Guinea Fowl sought refuge at the home of Orphan who was also vulnerable and knew how unjustifiable the world could be. He was wise to protect Guinea-Fowl. One good turn deserves another. After Orphan had narrated his miserable plight to the refugee, the refugee was honest and sympathetic enough to reciprocate the kindness and protection Orphan had given him. It was such circumstances that brought about the procurement of the two magic wands the first of which brought wealth (plenty cows) and the second of which saved him from being convicted at the traditional court.The narrator gave a vivid description of the way Guinea Fowl got the magic wands:

"U kyen ti mwaa gaa daa; ... "He went and cut a stock from an ebony tree

Nyəg lig, ka i pla, ka i ullu, ka i sebla. ... Made some stripes, white here, brown there and black over there.

$\boldsymbol{E}$ yelke uu de a na ti ton ... Then he instructed him to take the stick and use it to touch

A naa nader kpec ne gben yang. ... The forehead of one of the biggest bulls of the Chief ".

A naa nii in bun scble, ... Once, the Chief's cows are black

Ekye a u nii na in bun pelle"., yours will transform into white cows".

(Tale No. 3, by 61 yr old farmer from Nandom-Taayaga, 20th November, 2015). 
The above represents how witty orphan's new friend, Guinea Fowl was and how he was equally generous to turn Orphan's fortunes round so that he could also be rich and accorded the same respect and honour others received. It is important to look at the expression "nyog lig, ka i pla ka i ullu ka i scbla" and analyse its role in the performance and understanding of the tale. Literally, the expression means "made some stripes, white here, brown there and black over there". The narrator explained that the ebony stick is significant in Dagara tradition. First, the ebony tree is generally known as a "tengan tiع" (tree of the Spirit of the Earth). It cannot be used as a forked beam in roofing traditional homes for the Dagara because it is a taboo and nobody violates it. Neither can it be used as a straight beam in roofing traditional homes. However, when the ebony sticks are cut into smaller pieces, they can be used in roofing traditional homes.

If there is so much superstition associated with the ebony tree and it is the same stick that Guinea Fowl had cut and made stripes on it then one can imagine the kind of new power Orphan had received from his new friend. What reiterates the magical nature of the stick is "ka i pla, ka i ullu, ka i scbla" (white here, brown there and black over there). The repetition of " $k \mathrm{k} i$ " enhances the magical nature of the ebony stick. It reinforces the spiritual strength of the magic wand that Guinea Fowl had created for Orphan.

The colours on the magic wands are equally significant to the understanding of the tale. Upon interrogation, the narrator said that the white colour represents joy and fortune; brown means uncertainty and doubts whilst black represents mystery and urgency. By Orphan's cows being white they represent fortune for him and of course a deep sense of joy and relief. The Chief's cows were black and they represent the property of an important personality. However, when they vanished, it was a source of wonder and mystery to the chief. He did not believe that anybody had stolen them let alone confiscating them. To his ignorance, Orphan had transmogrified them into white cows to create a new kraal for himself.

When Gegera was also transmogrified into a donkey a situation of uncertainty and doubt was created. One wonders who was going to prosecute Orphan at the Chief's Palace. Once Donkey was not human it only made loud noise to the chagrin of the Chief. Though the expression "Maanu, maanu, maanu" in human terms meant "I am the one, I am the one, I am the one", Donkey was not a human be in to testify against the defendant Orphan. However, the expression "maanu" by Donkey is enough testimony that it was the one who went and summoned Orphan before the traditional court. The significance of the expression can therefore not be over emphasised. The terms "maanu" and "dgblu" are closely associated with Donkey. The narrator summed up Donkey's character by using certain human attributes that seemed to be manifested by Donkey. These character traits are understanding of human language (Dagara language), bravery, courage and stubborn attitude as explained by the narrator at the end of the performance.

The following words, terms and expressions form an important part of the diction of the narrator:

"Kpag nyuu" (lump on the neck meaning being rich)

"Vobli laa" (covered with an earthenware bowl)

"Nyəg lig" (made stripes on wood)

"Ka i pla, ka i ullu ka i sebla" (white, brown there and black over there)

"A zag nu u mwaaku a le" (that was how a kraal of cows was created for him)

"Tampellu viiri" (ashes around to form an oval shape)

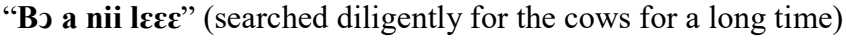

"Maanu, maanu, maanu" (I am the one, I am the one, I am the one) and

"Deblu" (bravery and courage)

\section{Assessment of Findings of the Study}

The following aesthetic features can be drawn from Tale No.1. Three hyperboles have embellished the tale significantly. After Yeng-Gang-Naa had named himself, his parents were spellbound and that amazement is represented in the following words: "One cannot describe the consternation that seized the hearts of the parents. To put it crudely their asses were hot and wide open that one could roast a tuber of yam there" (Kuwabong, 1992, p. 2).The effectiveness of this hyperbole underscores the apt description of the fear and awe that seized Yeng-Gang-Naa's parents as their child shocked them by speaking on the sixth day of his birth and even going further to name himself. This exaggeration captivates the attention of the audience. They experience shock and surprise and that mood corroborates the same mood Yeng-Gang-Naa's parents demonstrated earlier. The narrator's words are apt and they create a deep sense of humour aimed at embellishing the events of the tale.

The next example of exaggeration is reference made to the setting sun as we often observe on clear and sunny days. When wicked Chief Tamaa gave guinea-corn to Yeng-Gang-Naa's mother to brew "pito" (local beer of the Dagaaba) and serve the drink the same day to his guests, the poor woman saw that it was impossible to accomplish the chief's demand. She pleaded with the chief to give her enough time but the Chief refused to do so. Rather the angry Chief retorted to her plea and said: “Get off from my sight woman, miserable wretch that you are. I want the pito by the sun's red anus or else you and that rogue of yours called Yeng-Gang-Naa will smell pepper" (Kuwabong, 1992, p. 4). The personification of the sun with a "red anus" reveals the beautiful nature of the setting sun which ironically too, marks 
the rapid disappearance of daylight. The signs of the setting sun demonstrate the amber colour with sprinkled light rays across the western part of the sky. The vulgar term "red anus" reiterates the beauty of the setting sun as it comes into contact with various aspects of nature.

The literary aesthetics of exaggeration reinforces Chief Tamaa's urgent call for pito from the poor woman whose task could never be accomplished by the close of the same day that she got the guinea-corn. The context under which those words were uttered tells the audience that Chief Tamaa was not only desperate but also wicked and insensitive. In Tamaa's conspiracy to murder Yeng-Gang-Naa, he ordered Yeng-Gang-Naa should be given the best clothes to put on consisting of colourful smocks. Additionally, he rode a "strong ebony-black stallion". Ironically, "the chief”s son was given rags and a constipated donkey that let off "volleys of foul air with every step".(Kuwabong, 1992, p. 7)This Episode does not only reveal prolepsis (Chief Tamaa's anticipation of Yeng-Gang-Naa's death) but it also represents complete contradiction and reversal of the normal order. It also reveals the anxiety of the audience about the imminent danger that awaited Yeng-Gang-Naa.

The natural order of aristocracy was reversed and the disgusting portrayal of Tamaa's son was a timely bomb and trap which exploded and caught Chief Tamaa's son and Tamaa's own conscience. Peripeteia occurred when a reversal of the conspiracy fell on the Prince instead of Yeng-Gang-Naa. The Episode reveals the importance of plot (scheming, conspiracy) in human history. It sounds ridiculous to find a king turn plotter against a poor, insignificant subject he has complete control over in his kingdom.

In Genette's Narrative Theory Time's subcategory of "Duration" can be used to explain certain portions of the tale from the Opening of the tale until the Epilogue.From the Opening of the tale, the audience gathers the idea that the despotism of Chief Tamaa had persisted for a long time: "Any open sign of protest (from his subjects) was met with brutal repression. This went on until his twentieth year of enskinment". (Kuwabong, 1992, p. 1)The duration of time referred to here can be viewed as a situation of analepsis. The narrator wants the audience to know that Chief Tamaa's despotism had persisted for far too long.

Another instance of duration indicates the number of months that Yeng-Gang-Naa's parents had been married. It was just one year three months simply termed by the narrator as "in the fifteenth month of their marriage" (Kuwabong, 1992, p. 1). The sixth day on which Yeng-Gang-Naa sat up in his "cot of reeds" and questioned his parents about their feverish preparations to go somewhere, also reiterates the topsy-turvy nature of human development. This First Episode of the tale sets the right tone of the conflict which is full of twists and turns. It explains the situation of wonderment which leads to deception, treachery and betrayal on the part of the major characters. This creates suspense and a complete precipitation of the events of the tale. Obviously, the mood of the Audience, with all these details, sways between shock and awe.

A good leader is supposed to be an epitome of commendable governance and not extortion and deception. Eventually, Chief Tamaa confesses and regrets ('Harmatia') his wicked deeds. He accepts the fact that there are good and bad rulers. His abdication is a shameful admission of his foolishness, treachery and despotism. This act is a complete 'anagnorisis' (Revelation) as the audience see that the arrogant chief has realised and acknowledged the plain truth about the wisdom of Yeng-Gang-Naa who has lived up to the expectation and confirmation of the name he bore. YengGang-Naa was indeed wiser than Chief Tamaa.

Furthermore, the following conclusions can also be drawn from Tale Nos. 2 and 3.

The orphan-character is not just a solitary, miserable wretch but a resilient personality who strives to cope with challenges in life. His misery (as a character trait) is subsumed in his resilient and skilful abilities. Orphan's personality attracts humane and sympathetic people in his society to enable him make a complete volte-face. The cultural image of the orphan-character in Dagara folktales depicts him as an enduring, honest, sincere, diligent and an innovative personality. The Orphan Motif in Dagara folktales underscores aesthetic significance in terms of the major themes, moral and didactic lessons derived from the two tales. The Orphan is a metaphorical image of endurance, resilience, innovation and success in life. The law of retribution enables the orphan-character to liberate himself from his oppressors and he puts them to shame. Finally, the exposition of the Orphan Motif is based on the apt narrative skills used by the performers. e.g. Song which precedes narration of Tale No. 1

\section{References}

Agyekum, K. (2007/2013). Introduction to Literature ( $3^{\text {rd }}$ Ed.), Legon-Accra: Adwinsa Publications (Gh) Ltd.

Bauman, R. (1983). "The field study of folklore in context" in Handbook of American Folklore, ed.Richard Dorson. Bloomington: Indiana University Press, 362-368.

Bekye, P. K. (1991). Divine Revelation and Traditional African Religions, Rome, Leberit.

Boundas, C. V. (2007). The Edinburgh Companion to Twentieth-Century Philosophies Gt. Britain, Edinburgh University Press.

Chatman, S. (1978). Story and Discourse, Ithaca, New York: Cornell University Press.

Fischer, J.L. (1963). "The sociopsychological analysis of folktales”, Current Anthropology, The University of Chicago Press, 4, 3, 235-295.

Genette, G. (1980). Narrative Discourse Trans. Jane Lewin. Ithaca: Cornell University Press. 
Green, T. A. (1997). Folklore: An Encyclopedia of Beliefs, Customs, Tales, Music and Art, California, USA/Oxford, England: ABC-CLIO, Inc.

Hymes, D., \& Tedlock, D. (1975). "Breakthrough into performance," in Dan Ben-Amos and Kenneth Goldstein (eds.) Folklore: Performance and Communication.The Hague: Morton Press Internet: Growth of Folklore Theories: An Introduction. Available :www.ciitebooks.net/html/folkintro/ch2.html

Jahner, E. (1983). "Finding the way home: the interpretation of American Indian folklore" in Handbook of American Folklore, ed. Richard Dorson. Bloomington: Indiana University Press, 11-17.

Kabaji, E. (2012). The Maragoli Folktale:its Meaning and Aesthetics, Kenya: Kenyatta University. Available: http://irlibrary.ku.ac.ke/handle/123456789/4914

Kuwabong, D. (1992). Naa Konga and Other Dagaaba Folktales, Accra: Woeli Publishing Services.

Kyiileyang, M. (Forthcoming) Beyond the Moral Lessons: The Aesthetics of Dagara Folktales, Ongoing Ph.D Dissertation Material.

Kyoore, P., \& Sikyoghrkur, B.K. (2009). Folktales of the Dagara of West Africa, Accra-Ghana,Qolyns Skan Multimedia Limited.

Magoulick, M. (2012). "History of Folklore” Available: www.faculty.de.gcsu.edu|

Okpewho, I. (1992). African Oral Literature: Backgrounds, Character and Continuity, Indiana and Bloonington, Indiana University Press.

Prince, G.J. (1973). A Grammar of Stories: An Introduction. The Hague; Paris:Mouton.

Tedlock, D. (1978). Finding the Center: Narrative Poetry of the Zuni Indians. Lincoln: University of Nebraska Press.

Thompson, S. (1955). "Motif-Index of Folk-Literature:A Classification of Narrative Elements inFolktales, Ballads, Myths, Fables, Medieval Romances, Exempla, Fabliaux, Jest-books and Local Legends”. Rev. and enlarged ed. 6vols. Bloomington: Indiana University Press.

Yankah, K. (1989). The Proverb in the Context of Akan Rhetoric-A Theory of Proverb Praxis. NewYork: Peter Lang. 